Article

\title{
A New Orthodox Synagogue in Manhattan: Decision-Making and Design
}

\author{
Carol Herselle Krinsky \\ Department of Art History, New York University, New York, NY 10012, USA; chk1@nyu.edu
}

Received: 27 July 2019; Accepted: 28 August 2019; Published: 4 September 2019

\begin{abstract}
The Lincoln Square Synagogue, the largest Orthodox synagogue built in Manhattan during the last half century, was established in 1964 but moved in 2013 to a new building nearby, designed after the firm of CetraRuddy Architects, won a design competition. The present article is based on interviews with building committee members, the rabbi, and the architects as well as on press accounts and a book about the congregation's history. The article recounts the process of designing the building, assesses the successful results, and provides future building committee members with ideas, caveats, and evaluations of design procedures.
\end{abstract}

Keywords: synagogue; orthodox; sanctuary; building committee; CetraRuddy Architects; Rabbi Shaul Robinson

The new Lincoln Square Synagogue, one of the only two large Orthodox synagogues built in Manhattan in over a half century, stands on Amsterdam Avenue on the Upper West Side, north of Lincoln Center for the Performing Arts and close to apartment buildings housing a good many Orthodox residents, A group of neighbors led by Daniel and Emma Margolis, who needed a house of worship within walking distance of their homes, organized a temporary congregation for the High Holy Days in 1964 and engaged a young rabbinical graduate Steven (later Shlomo) Riskin, to lead the congregation. ${ }^{1}$ Even if not all fully committed to Orthodoxy, the members agreed to follow the rules that the pious young man specified. The congregation is Modern Orthodox, which is close to the practices of the United Synagogue in Great Britain; the present rabbi, Shaul Robinson, formerly led its Barnet congregation in suburban London.

Rabbi Riskin was not hired simply because he was available and affordable, although those were the initial considerations. He was so engaging in his devotion, deep scholarship, and oratory that the group canvassed the neighborhood, enticing others to theologically exciting services that some had earlier forsworn or neglected in Manhattan's religiously permissive environment. The congregation met at first in donated apartments at Lincoln Towers, a housing development on West End Avenue. Its owner, the Alcoa Corporation, hoped to entice congregation members to rent apartments in buildings that were hard to rent at the time, being near the western edge of Manhattan and just north of a district known as Hell's Kitchen. The Corporation confirmed its commitment by backing a mortgage for the construction of a synagogue on a parcel of land at 200 Amsterdam Avenue that the corporation owned.

Rabbi Riskin continued to insist on certain rules and practices which even reluctant worshippers respected and often followed. As word spread about his charismatic oratory, the congregation grew rapidly. The members left their rented premises in 1970 for a synagogue designed in 1966 by Hausman \& Rosenberg with 475 seats. Made of reinforced concrete in a circular shape articulated outside by

1 The history of the first Lincoln Square Synagogue is told in (Abramson 2008). See also publications in notes 2 and 4 below. Information about the architects can be found in the Guide to the Stanley R. Rosenberg Architectural Records 1952-1985 at the New-York Historical Society. 
broad curving travertine-clad walls and vertical fins that provided some security against vandalism, the synagogue presented a modern and stylish appearance, suggesting that Orthodoxy could be forward-thinking (Figure 1).

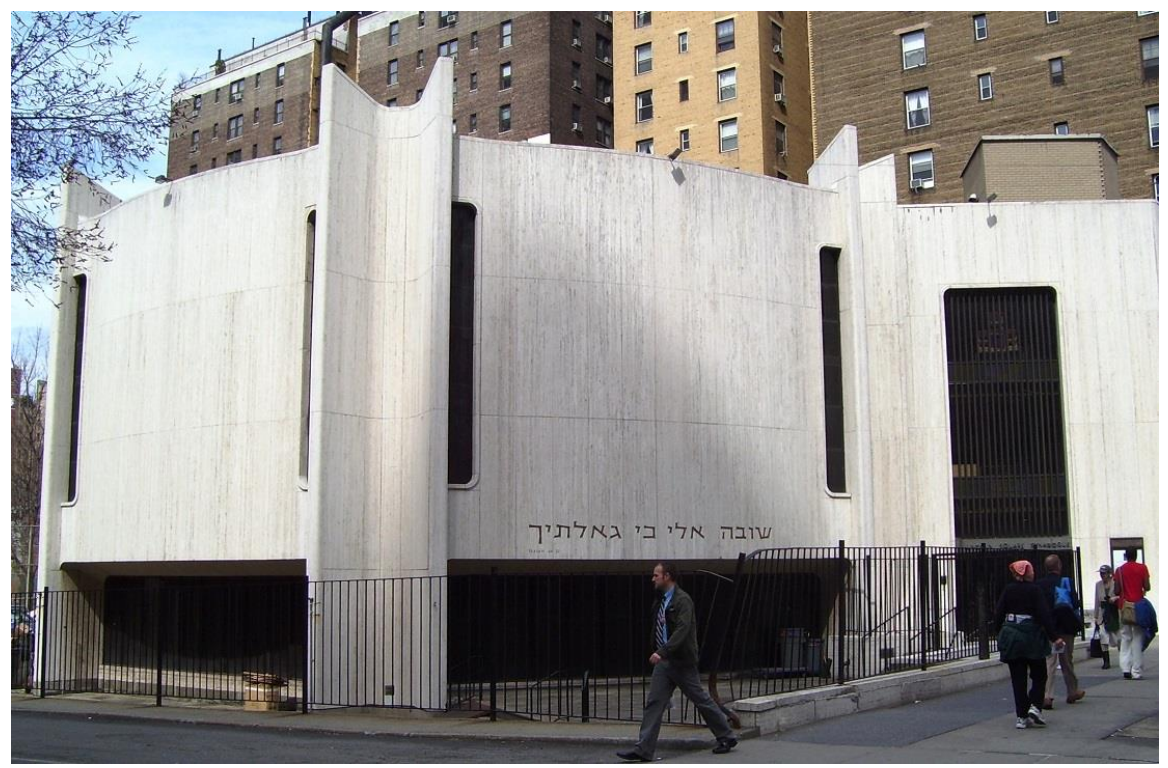

Figure 1. Lincoln Square Synagogue, 1966-70, Hausman \& Rosenberg, photo Wikimedia Commons, accessed 22 July 2019. Used by permission.

The wood-lined circular interior sanctuary was divided by a mechitza, a barrier separating men from women. The seats were arranged in banked pews. It was nevertheless possible for men and women to see each other. Congregants faced the bima at the south; a hexagonal skylight rose above it. Twelve long, narrow windows contained stained glass that represented the twelve tribes of Israel (Figure 2).

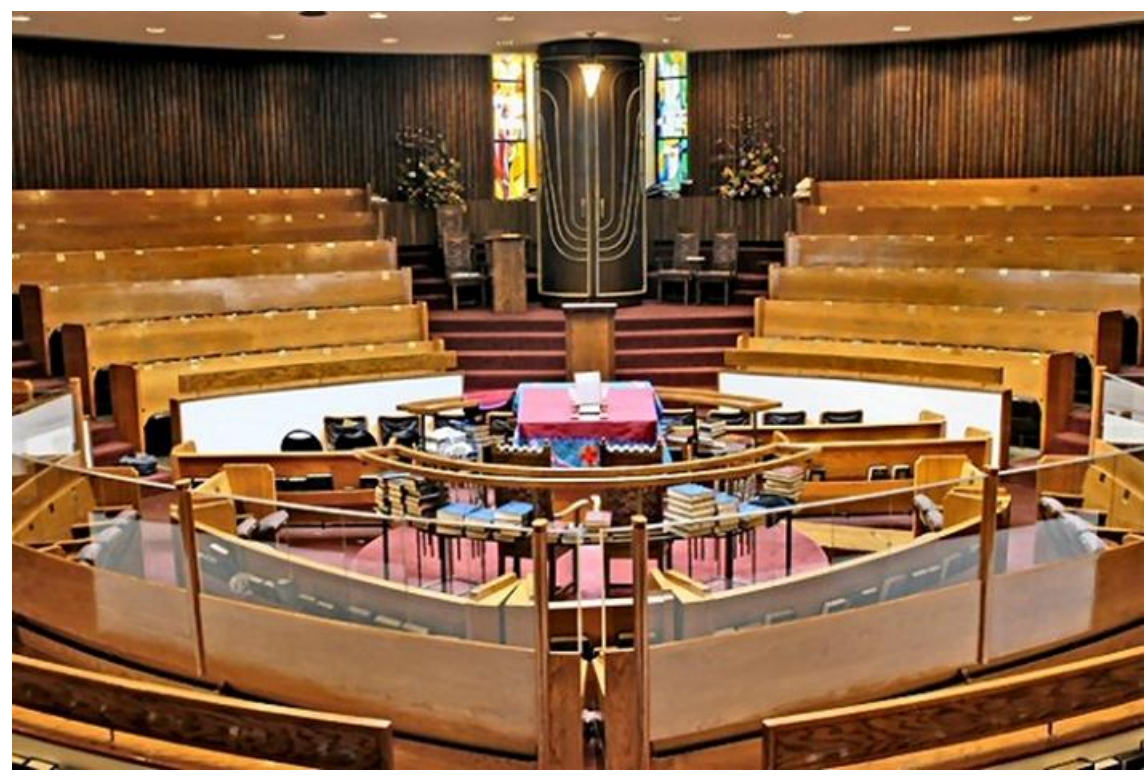

Figure 2. Lincoln Square Synagogue, 1966-70. Interior. Photo: jewishparentingguide.com No copyright infringement is intended.

As the congregation soon swelled, the sanctuary became too small for a single Sabbath service. The cantorial talent of Sherwood Goffin was an additional attraction. The solution was to arrange auxiliary 
services for women and special-interest groups. These measures could not compensate for the small lobby that forced people to gather outdoors even in winter, lack of accommodation for the disabled, inadequate exits and, by the new millennium, a decaying physical structure. After Rabbi Riskin emigrated in 1983 to Israel's West Bank, several successors continued his mission (Landowne 2013). Nevertheless, competition from other synagogues and the movement of young families to larger apartments or suburban houses caused the congregation to decline from about 1000 in the 1970s and '80s to under five hundred in 2013 (Rosenblatt 2013), with aging members.

In about 2005, American Continental Properties (ACP) offered to trade the site of the synagogue and an adjacent former bank for a 12,000 square foot plot of land about one hundred feet south ... . The address, 180 Amsterdam Avenue, was selected to include the number 18 within it, because of its connection to the word chai, or life, in Jewish numerology. The generous access granted to me by the current rabbi, Shaul Robinson, members of the governing board, and CetraRuddy Architects, designers of the new synagogue, have made possible an account of building a modern Orthodox synagogue that includes the motivations and the decision-making by the building committee and the architects, advice for future synagogue building, and the congregation's response to the new home. ${ }^{2}$

When ACP made its tempting offer with an infusion of $\$ 30$ million (Dunlap 2013) for the new construction, Rabbi Robinson and the congregation's leaders prepared a list of requirements. The building committee then interviewed architects experienced in synagogue design, including major firms such as Perkins-Eastman, and respected architects including Alexander Gorlin, and the Gund Partnership. Applicants were known to responsible individuals in the congregation. A person with whom CetraRuddy had business relations made the firm aware of the project, assuring the building committee that the firm was capable of creative solutions that followed a client's mission, even if these architects had not previously designed a synagogue. The architects plunged into a program of research, since most of the firm's participants in the project were Christian. They traveled widely to visit synagogues in several countries and read books about historic and modern architecture for Jewish worship and for spiritual expression. ${ }^{3}$ Their research revealed certain constants but not a specific form or style. Those matters would have to wait until the congregation produced a full program.

When the congregation's active and deeply-engaged building committee reduced the number of competitors from sixteen to four, its members invited the final group to present ideas for the building. CetraRuddy was told to go first, usually not the position of choice, as later presentations may benefit from contrast with what has preceded them. The firm's principals were dismayed to see that the other three competitors had prepared models of the future building, albeit concealed under wraps. CetraRuddy provided hand-drawn sketches that expressed elemental qualities such as light, form, community, and connectivity. John Cetra could not imagine designing a building without knowing what the congregation itself hoped for, so he forthrightly explained the absence of a specific shape, promising sincerely to design the building "from the heart" after serious consultation with the governing board. Nancy Ruddy helped to persuade the congregation's representatives that the firm wanted to design a synagogue, not for the money but for the sake of a vision. She saw the design of a new synagogue as an opportunity for the congregation to redefine its mission, and assured them that the architects would undertake a kind of journey with the members to create a meaningful building.

2 Principal informants in the congregation were Scott Liebman and Shelley Richman Cohen, interviewed in March, 2019.

3 The architects found the following books most helpful, among the many that they consulted: H. Meek (1995), The Synagogue; M. Levin and J. E. Young (2004), Jewish Indentity in Contemporary Architecture; S. Gruber (2004), American Synagogues: A Century of Architecture and Jewish Community; H. Stolzman and D. Stolzman (2004), Synagogue Architecture in America; E. Torres (2005), Zenithal Light; M.S. Millet (1996), Light Revealing Architecture. They visited the following synagogues in the United States and abroad: Newport, Rhode Island; synagogues in Venice, Amsterdam, the Paradesi Synagogue in Kochi, Kerala; others in New York City. They looked at modern synagogues and places of worship designed by Louis Kahn and LeCorbusier, as well as the Rothko Chapel in Houston, Texas. They derived information from internet references to the Torah, especially from Exodus, concerning the making of the Tabernacle. The Torah also supplied suggestions for material such as the cedars of Lebanon, bronze, and stone. Appreciative comments about the synagogue have been made by James Gardner (2012), Morton Landowne (2013), and Marco Rinaldi (2013). 
The congregation's well educated and sophisticated leaders approved of this approach; they did not want the kind of synagogue that looked like a reinforced concrete tent in the wilderness or a six-pointed star. A board member later told Mr. Cetra that after his open-minded and forthright presentation, his colleagues were distracted from the more specific presentations that followed.

Members of the building committee say that their choice of the CetraRuddy firm was based on the architects' understanding of the proposed project and their ability to express the congregation's Jewish values through their designs. They preferred the subtle and extensive references offered by Ms. Ruddy, by her husband and partner, Mr. Cetra, who was the principal architect, by his co-designer, Theresa M. Genovese, the managing architect and fellow principal, and later by Branko Potocnik, an associate principal active in the interior design. The architects' concepts were based on research into Jewish texts, actions during prayer, and symbols interpreted literally but subtly. The building committee found their concepts to be the most creative-related to the architects' search for the essentials of Judaism, not for a style ${ }^{4}$ (Figure 3).

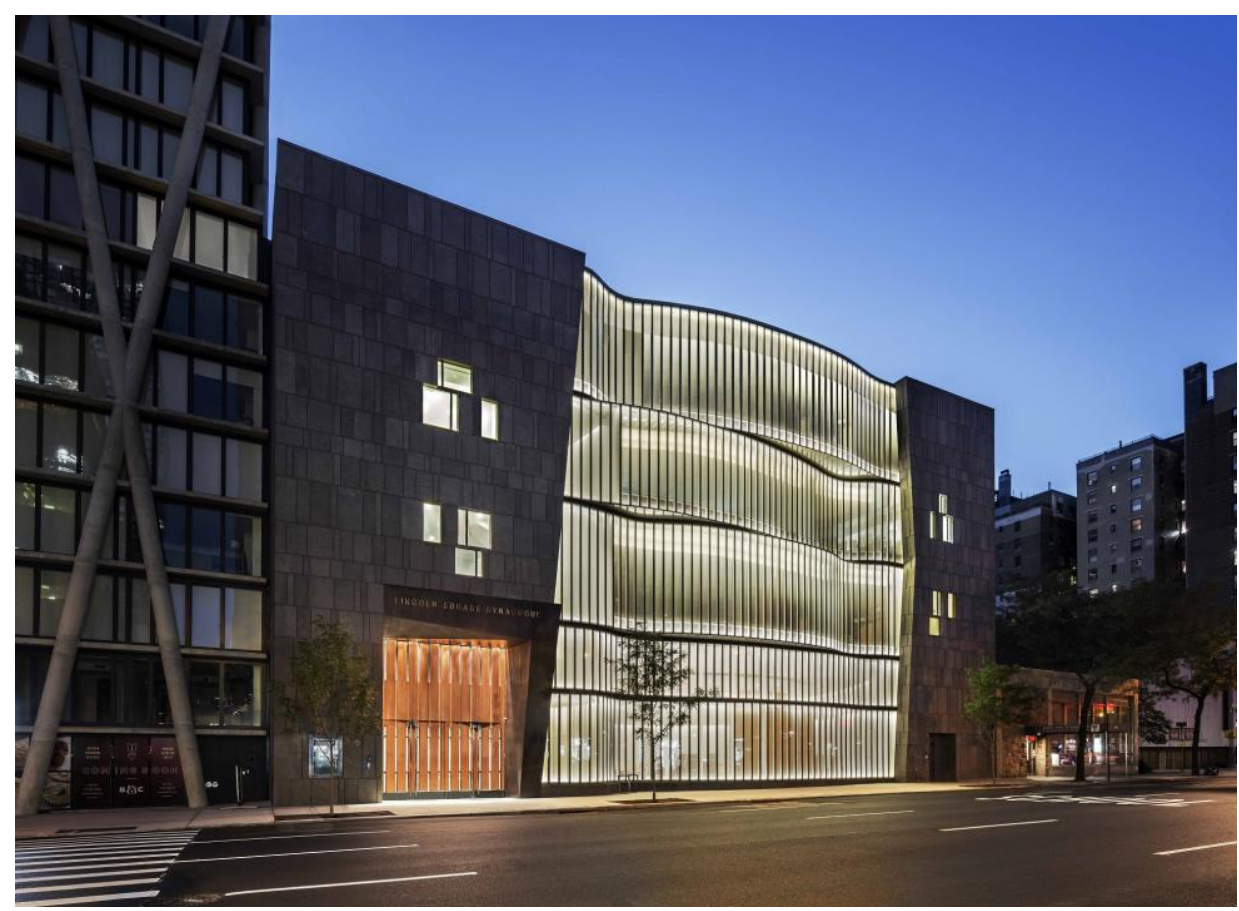

Figure 3. Lincoln Square Synagogue, 2005-2013, Cetra/Ruddy. Photo David Sundberg/ESTO. Exterior at dusk.

While the five-level façade of waving glass bounded by firm verticals alludes to the five books of Moses and evokes the idea of unrolled Torah scrolls, one has to discover these analogies. The idea for motion in the façade came to Mr. Cetra after his first visit to the former synagogue when the members put on their shawls and prayed in the davening motion, back and forth, after "greeting one another fondly and respectfully" (Dunlap 2013). While inspiration came from actual Torah scrolls, the idea of constant movement during prayer, including the motion of the shawls, influenced the entire design. This is the result of attentive observation of the activity within the building. For the casual viewer, the façade might simply provide gentle relief from an aggressive concrete façade on the apartment house at 170 Amsterdam Avenue to the south, or the rectilinear simplicity of a lower, smaller former public library immediately to the north, now the Reconstructionist West End synagogue. It takes longer to discern that the thin bronze-colored fabric laminated into glass panes suggests the texture of parchment

4 Interviews with Mr. Liebman, Ms. Cohen, Rabbi Robinson. 
used for the scrolls. The architects worked hard to find a pattern for the stone panels flanking the glass façade, hoping to refer to prayer shawl design there as one enters the building. These analogies can be ignored or can elicit thoughts about the primacy of sacred texts and practices. If the rusticated north façade and terminations of the east façade do not immediately evoke the "protective covering for the Torah and the tabernacle within," the architects' suggestion of that form can be imparted to the congregation. These references are subtle enough to allow the synagogue to fit into the cityscape and yet suggest aspects of tradition. Congregation members are more likely to understand the rusticated main lobby wall's beautiful (but economical) Chinese-quarried stone in the lobby as an echo of the Western Wall in Jerusalem; evocation of the wall is now common in modern American synagogue design. (Figure 4) The suppliers of the stone, Walker Zanger, found a stone with the suitable visual effect, and its installation later won an award.

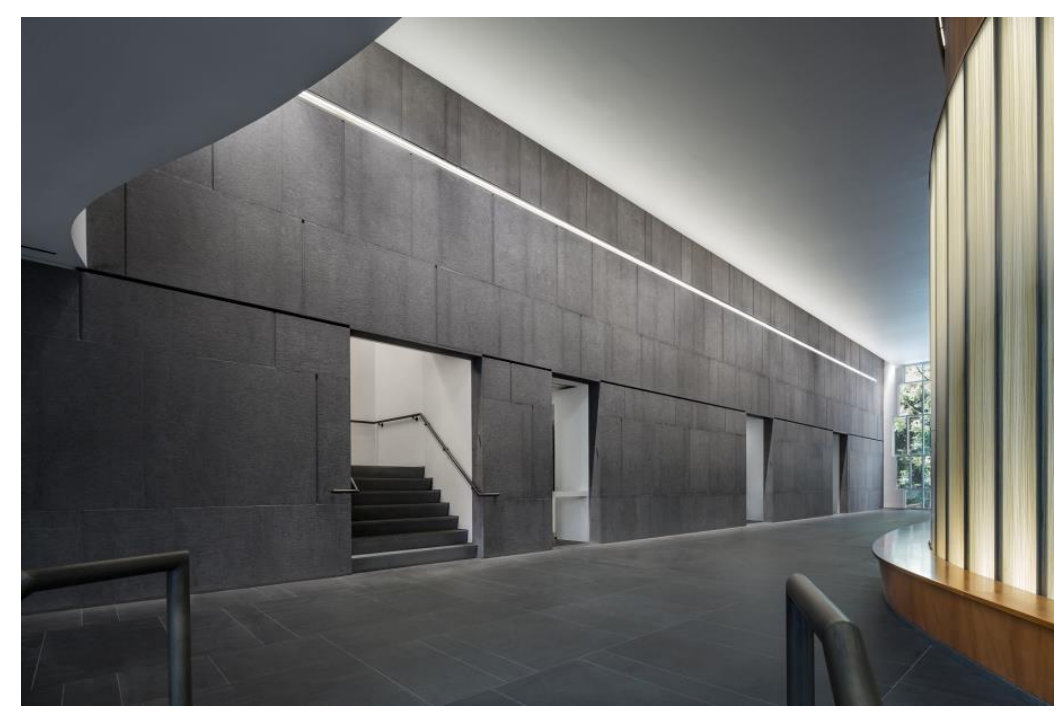

Figure 4. Lobby, Stone wall on south side of lobby, looking west. Photo David Sundberg/ESTO.

Cedar of Lebanon-albeit obtained in Italy_-veneers the main entrance doors and the lobby (Figure 5).

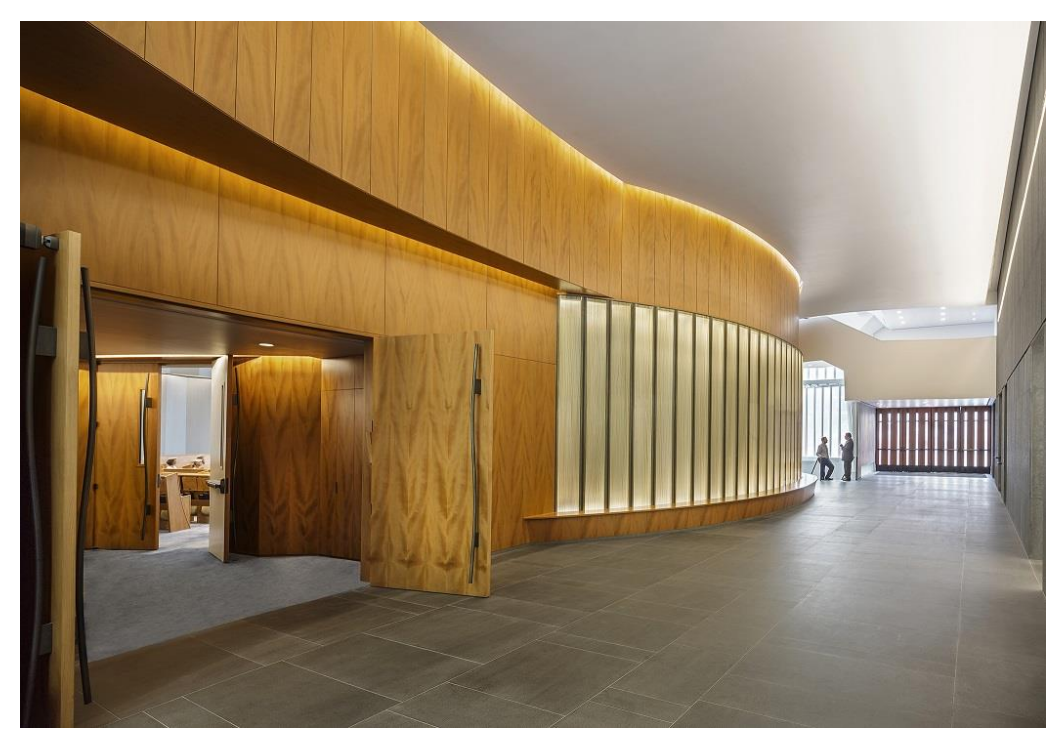

Figure 5. Lobby, cedar wall on north side of lobby, looking east. Photo David Sundberg/ESTO; on the left side is a view from the lobby recess into the sanctuary. 
Antiqued bronze at the entrance, on handrails, and elsewhere in the synagogue refers to bronze appurtenances mentioned in the Bible. The building committee members were favorably impressed by the architects' research, analogies, and solutions to material and economic problems. They expected and received what they called a forward-looking synagogue, able to satisfy the older members and also the younger members who were embracing more Orthodox practice.

The architects had also to fulfill practical aspects of the program on a site measuring 120.42 feet north-south on Amsterdam Avenue, and 100 feet east-west. In order to satisfy both functional and spiritual requirements, they conducted well over two dozen interviews including those with the building superintendent, the head of education, the people who installed the books in the beit midrash, the oldest member of the congregation, and board members. From these interviews, the architects determined spatial needs, the desire for wooden bookshelves, the requirements for seating, and other practical matters. During the six-month process of determining the final program, the architects became acquainted with the entire operation of the building, ranging from small things such as an extra burner for producing cookies quickly for receptions to providing a place for parents to retreat with crying infants, a cloakroom large enough to accommodate many baby strollers, and discreet provisions for aging or disabled members.

The building committee, formed by the congregation's president, included practical thinkers, people experienced in real estate, and others who had little experience of building. They met primarily during evenings but also committed other hours to planning, and appeared energized by being part of the process; they did not leave the thinking to the architects and a small coterie. The process was collaborative and inclusive. Conversation joined by the building committee, the congregation, and the architects led to a thoughtful and responsive solution. Most of the members were in favor of what Rabbi Robinson called a "high end" design. That can, of course, be costly.

Not all good plans work perfectly. It is vital for a congregation to select an owner's representative who understands the congregation's goals and can guide them to the correct solution. The first of the owner's representatives-there have been two principal ones over time and three construction managers-presented a program before the building was designed and thus presented an unrealistic budget. Even economical measures such as the use of acoustical tile had to be revised. He chose non-union labor to save costs, but during a period of active building in the city, he could not hire a construction company able to do the work for the fee proposed; later, the synagogue had to pay $\$ 2$ million to someone dismissed who instigated a lawsuit. Steel was ordered and erected incorrectly; that and delays had to be dealt with. Perched water found in the substrate caused water infiltration and delays. Other below-grade problems arose as well. The original sub-contractor had not followed the engineer's drawings, nor did the waterproofing sub-contractor follow CetraRuddy's drawings. These and other problems illustrate the need for clients to select the right construction manager who becomes the architects' partner, and then to select the right contractor. Three successive contractors who were low bidders but inexperienced in complex and high-quality design prolonged the construction period.

Work stopped in 2010, but since the previous synagogue had already been sold, the only solution was to continue to build despite the increased cost. A synagogue member gave $\$ 10,000$ to hire a construction auditor. At last, an anonymous donor, known as the White Knight, rescued the project by presenting over twenty million dollars. As congregation members were asked to raise three million more, the synagogue took out a mortgage for this sum. Some expenses were cut; for instance, a flat ceiling replaced a distinctive curving ceiling over the multi-functional room. At present, the building and its maintenance staff are supervised by Tamar Fix, the synagogue's Executive Director.

The facilities on the first (ground) floor are organized as if congregation members were on a journey. They enter the spacious wood-veneered lobby and encounter a hall, where, at the entrance, a staircase fitted into a curve of the façade sweeps down to the lower level and the multi-functional room there (Figure 6). 


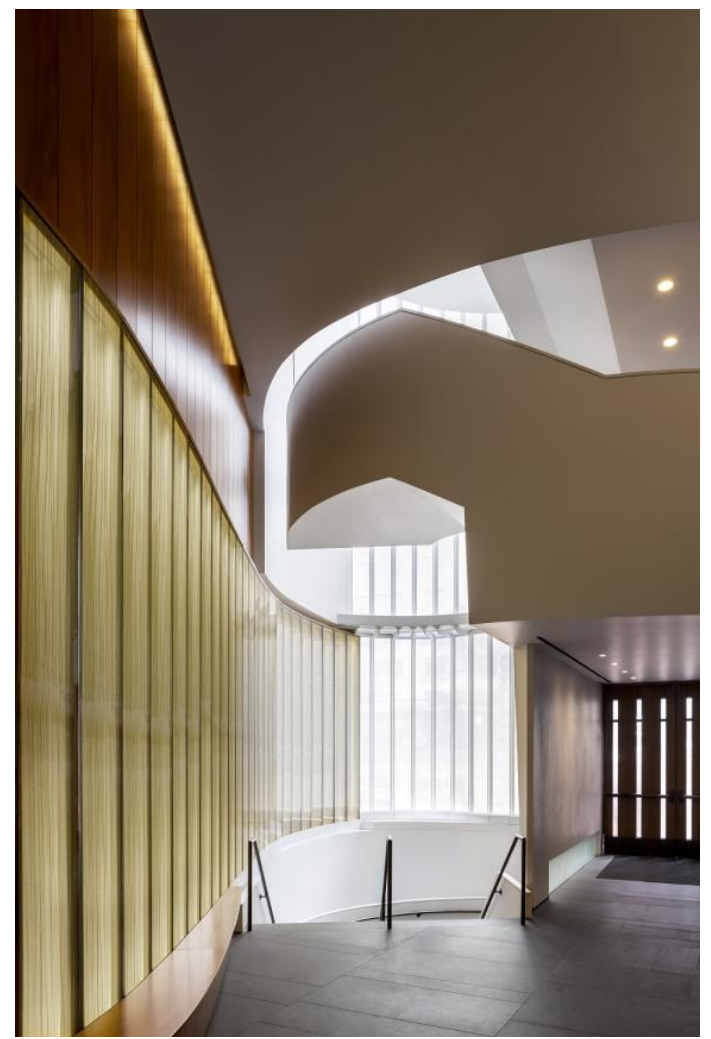

Figure 6. Entrance doors (right). Stairs (center) down to multi-functional room. View to east with part of curving façade. Photo David Sundberg/ESTO.

Ahead, a large window at the far (west) end offers a view of daylight and nature (Figures 4 and 7).

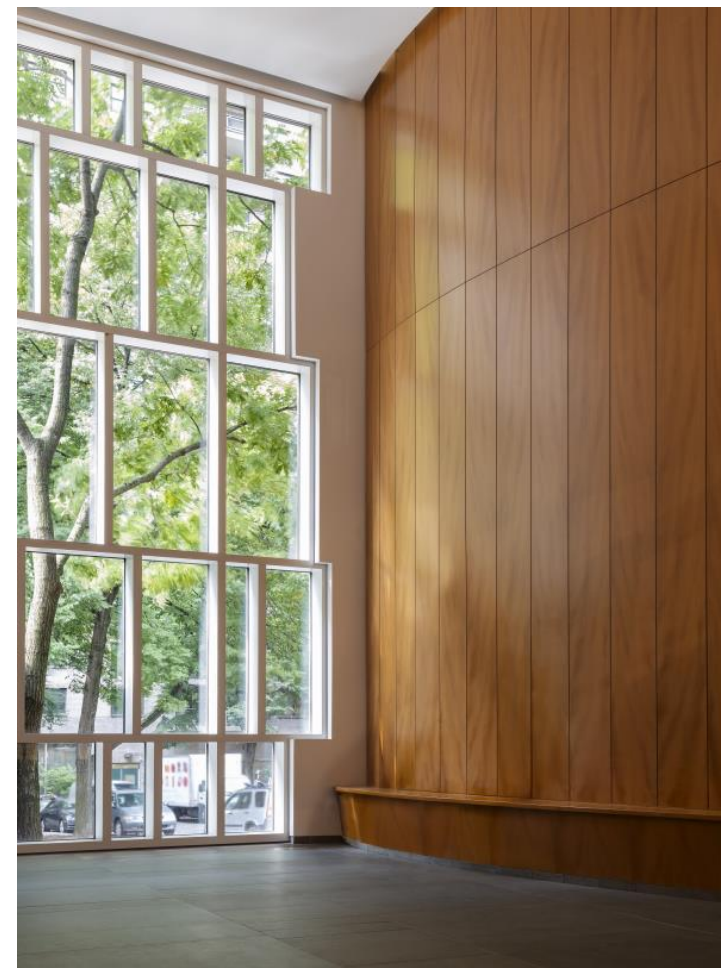

Figure 7. West window, and part of north wall of cedar. Photo David Sundberg/ESTO. 
To the left are storage areas and restrooms and the wall partly covered in stone. Opposite, a curved wall suggests movement to the right, past a lobby that directs worshippers into the sanctuary. A recess from the lobby gives the final access to the sanctuary, allowing a mental pause between the social and community area and the ritual space (Figure 5).

The sanctuary, of course, was the primary space to be designed, and the congregation wanted a circular one familiar from its first building. They saw this as reflecting the equality of men and women despite the specific roles assigned in Orthodox Judaism to each gender. The architects proposed a slight and at first glance imperceptibly elliptical form, in order to accommodate 442 people. The geometry of the walls enhances the acoustics while obeying the Orthodox imperative to avoid mechanical sound amplification during prayer. The angled and undulating walls were also intended to evoke the tabernacle in the wilderness that sheltered the biblical Ark of the Covenant. If not everyone recognizes the analogy, the congregation's decision-makers understood the reference when the architects presented it. A ramp along the synagogue's walls brings wheelchair users so subtly down to the bima that their movement is hardly discernible to most of the congregation; in the previous synagogue, wheelchairs could not reach the bima. However, the ramp is useful primarily to lead anyone gently and easily to a seat; the architects found forms that accommodate everyone rather than separate elements suiting only limited groups (Figure 8).

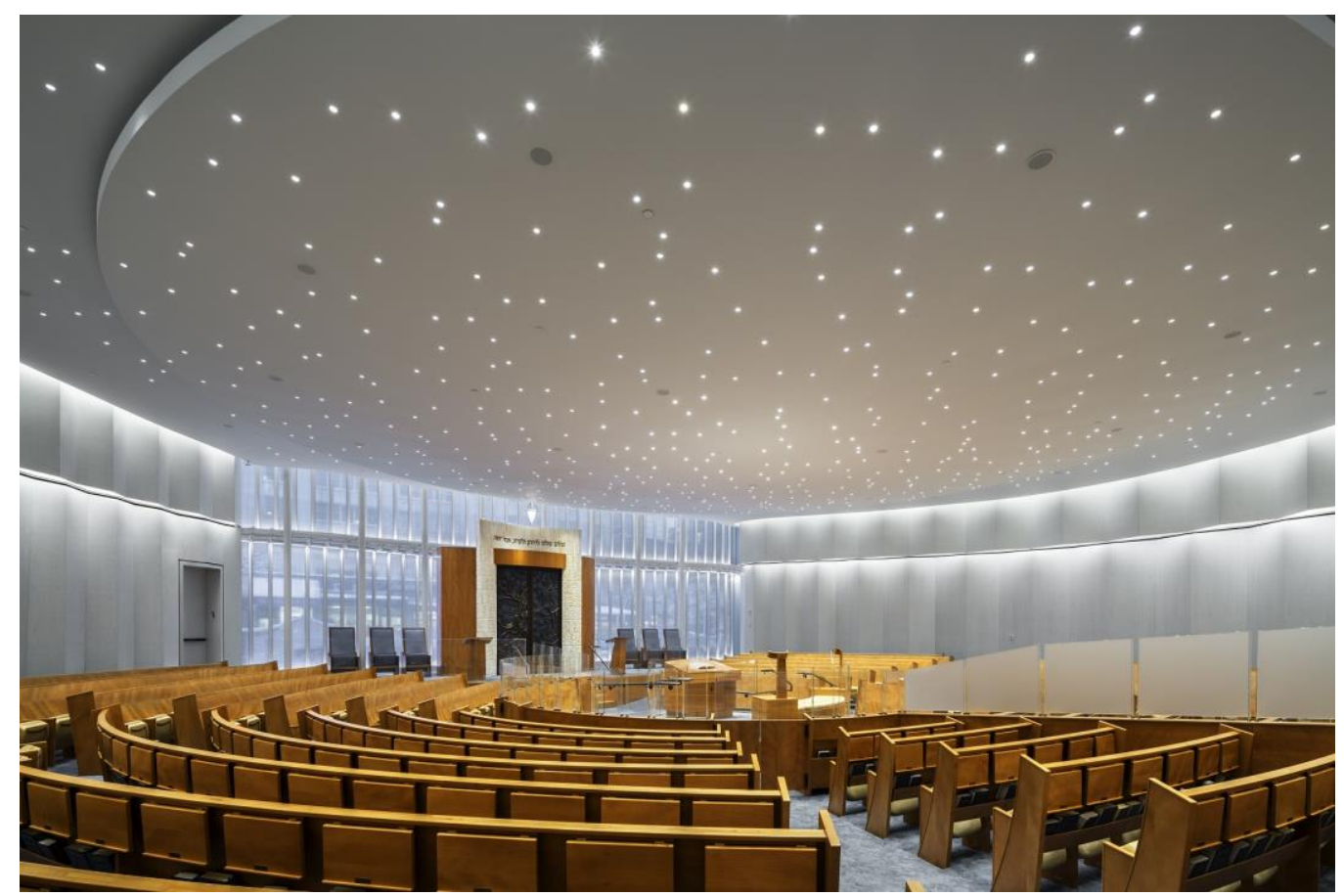

Figure 8. Sanctuary interior. Photo David Sundberg/ESTO.

Discussion arose about the configuration of seats. No one wanted to relegate women to a position behind the men; this raised the challenge of designing a mechitza that would cut the interior in half. The rabbi, building committee, the architects, and the congregation spent long hours in search of the most inclusive seating solution that respected the rabbi's interpretation of Jewish law. The architects devised a glass mechitza that is partly transparent, partly translucent to shield views of the other gender, and high enough to provide separation while not interrupting the room's strong volume. The mechitza continues into a glass enclosure for the bima. A person sitting behind the center of one of the enclosing panels can see the activity around the bima but cannot be seen from it; this is essential for women and for the men, who must avoid the sight of women during the services (Figure 9). 


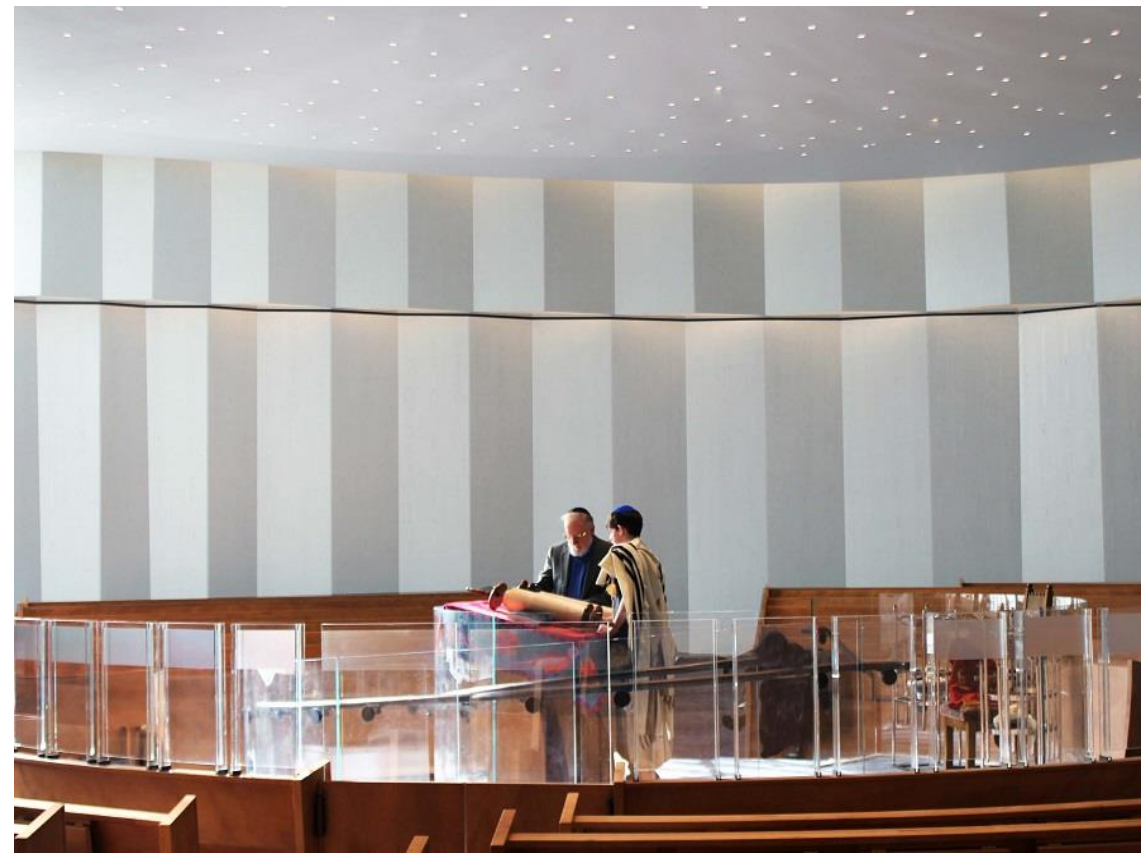

Figure 9. Sanctuary interior. Mechitza around the bima, showing clear and more opaque glass. Photo David Sundberg/ESTO.

The room is colored in soft and restful tones, with pale hues bringing warmth, and cool colors creating calm balance. Gentle indirect lighting from two recesses around the sanctuary walls provides good illumination that can be modified (Figure 8). The ceiling is a soft blue, reminiscent of the sky, and concave to evoke the sky over the most ancient Biblical site of prayer; it may also refer to that color in the Torah. The walls are made of wood, washed in a pale gray-blue. The light-filled sanctuary space, including natural light from a tall window behind the ark, is both beautiful and important to the congregation. Near the door on one side, perforation holes assist the acoustics; the acoustical engineers originally wanted more of them but the architects did not. The custom-designed carpet in tones of blue is well maintained in the sanctuary but less so in the surrounding corridor, revealing the problems that arise after a building has been in use for some time. This quiet sanctuary is given a perhaps jarring note by the heavy ark and the chairs flanking it, designed at the building committee's insistence by a firm that specializes in these installations; the company is known for using Jerusalem stone in its products. The furniture around the bima is too heavy to move for the wedding canopy to be affixed most attractively. Although these elements are inconsistent with the otherwise integrated design, the spirituality of the sanctuary remains undisturbed. The congregation and architects did not install murals, colored glass, or inscriptions.

The feature of the interior that is usually most remarked upon is the ceiling, with 613 small lights representing 613 mitzvot (divinely ordained precepts and commandments) and the clear desert sky above the original nomadic tabernacle. Early designs had fewer lights, but the committee promoted the easily-understood idea of being in contact with the mitzvot during the services, and members were delighted to learn about this symbolic gesture. The inspiration for many lights came from the architects, but a building committee member suggested increasing the number to 613 .

Apart from the sanctuary, a major requirement was a beit midrash with a capacity of about 150 people. It is a spacious and well-lit room on the second floor, lined with Cedar of Lebanon bookshelves. It accommodates an ark and bima, seats and desks, and areas for discussion and devotion. A low wall separates the prayer area from the rest of the room. The ark and bima are undistinguished in design but have meaning for the congregation because they came from the former synagogue (Figure 10). 


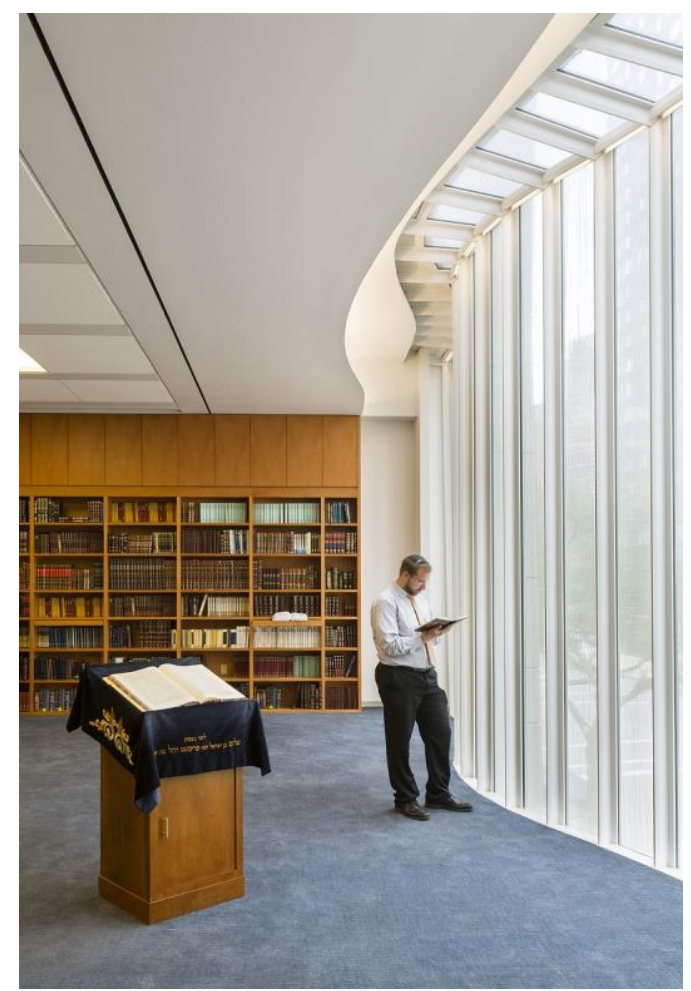

Figure 10. Beit Midrash, detail. Western glass wall. Photo David Sundberg/ESTO.

The building also needed a spacious entrance lobby to accommodate the members who had had to cluster for conversation outside the former synagogue's cramped lobby (Figures 4 and 5); they often conversed in the street. The new building provided classrooms, storage areas, cloakrooms and restrooms, and an approximately 6800 square-foot multi-functional ballroom below grade for banquets, receptions and even children's indoor sports. The program also specified a rabbi's study, offices for auxiliary clergy, large and small kosher kitchens, and an outdoor rooftop area for Sukkoth dining that can accommodate almost three hundred people who may bring their own food or order some on site. The idea was to have everything that a religious community needs in one building. The third floor was to be income-producing, with rooms for potential rental to religious organizations such as a charity or a nursery school; at present, they are rented, as are additional spaces on the second level. In addition to the desired programmatic spaces, state-of-the-art mechanisms for heating and cooling, provision for electrical installations, water supply and drainage, and other infrastructure had to be fitted into the limited urban site (Figures 11 and 12).

The congregation is proud of its building but to supplement its operating funds, pay its staff and assure ongoing maintenance, it insured that the design of its multi-functional basement ballroom and some other rooms could accommodate congregational uses as well as rentals to appropriate groups and for events connected to Judaism. It handles its High Holy Day overflow crowds by holding multiple ceremonies so as not to violate the city's building safety code which also requires multiple Sabbath services when many people come to the synagogue. 


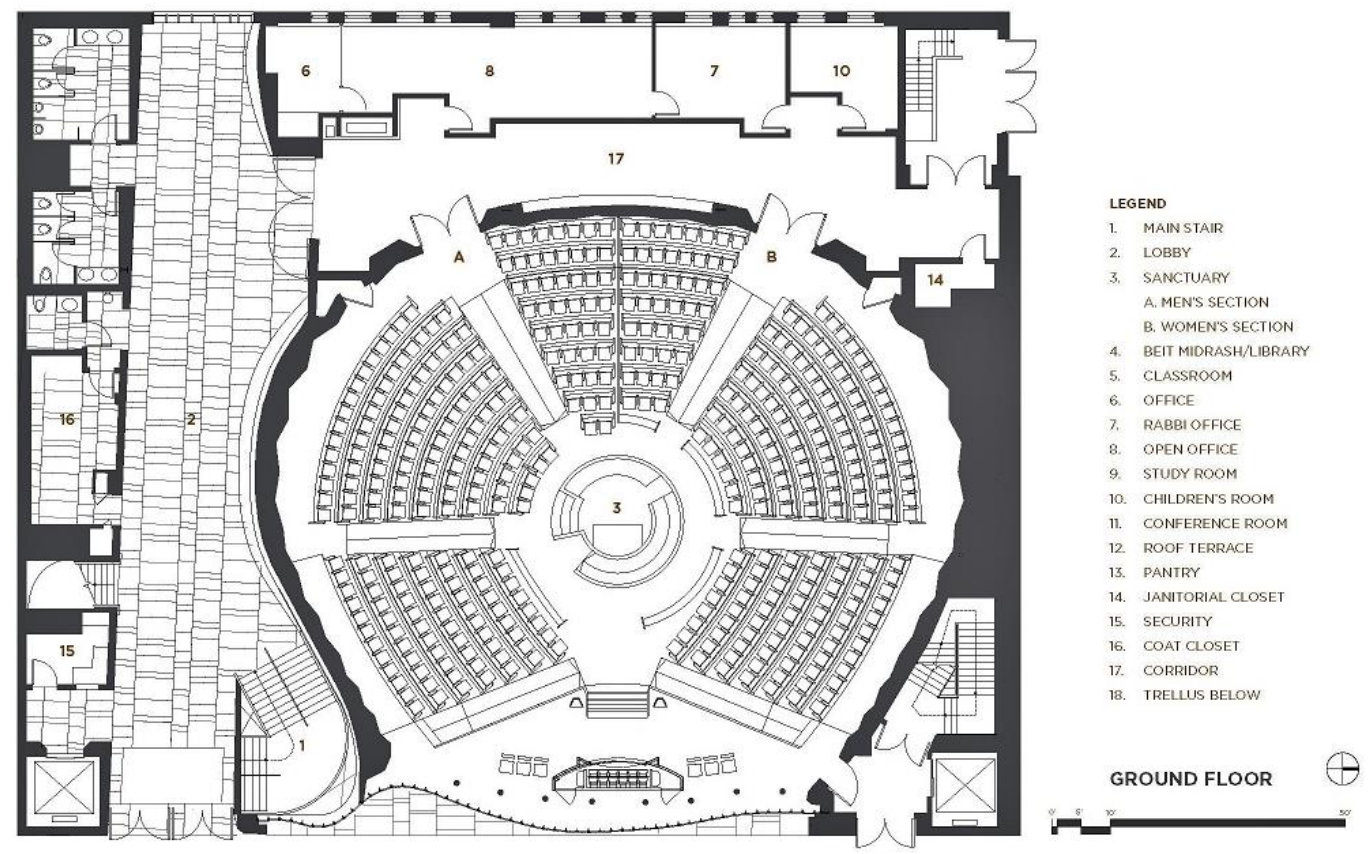

Figure 11. Plan of the ground floor. North is on the right. Courtesy CetraRuddy.

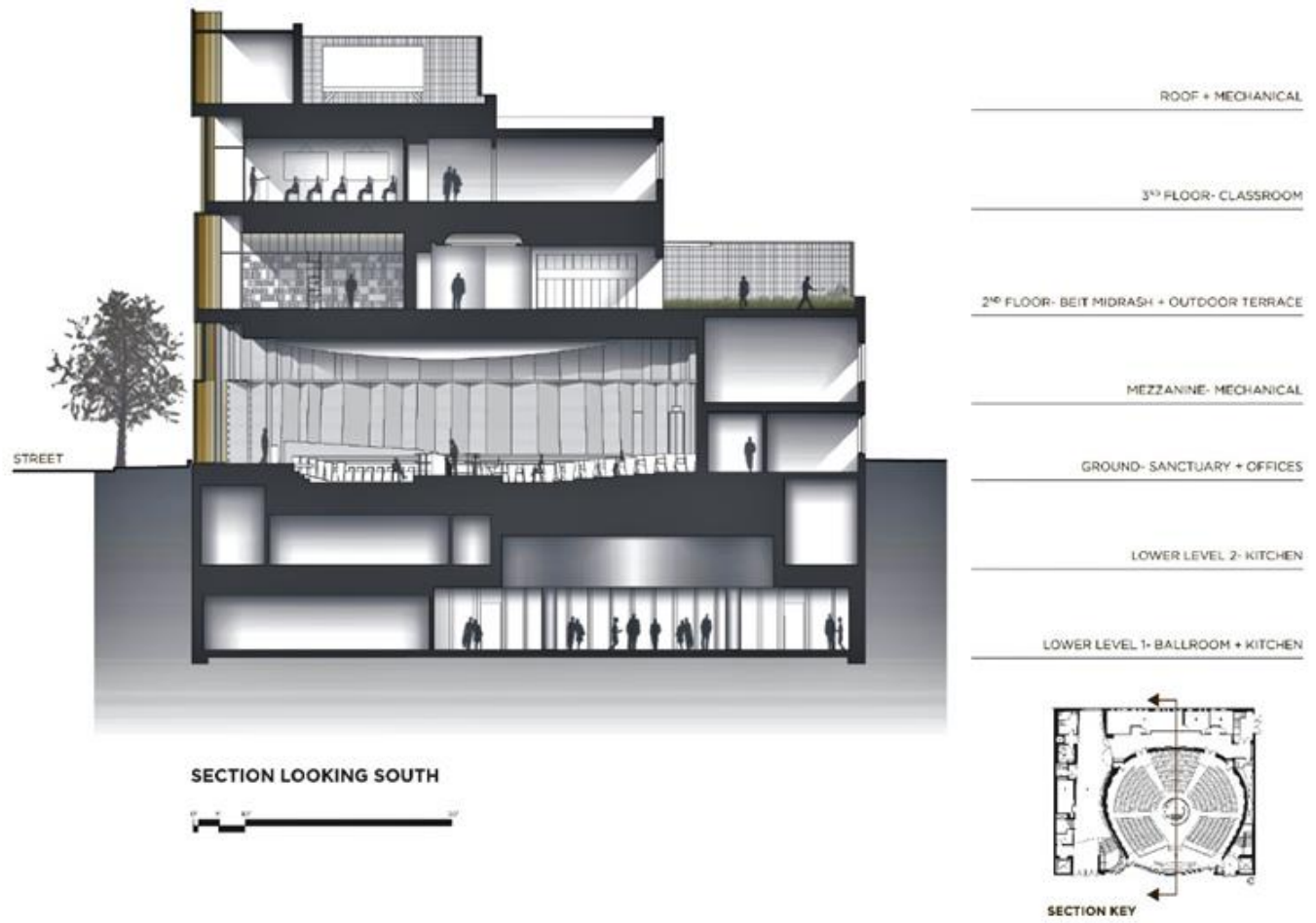

Figure 12. Section looking south. Courtesy CetraRuddy.

It is necessary for the architects to make occasional visits to assess the condition of the building and to handle the city's rules and inspections; if a congregation chooses its architect well, a representative of the firm will be available for occasional consultation and support. These and other circumstances need to be discussed with existing synagogues and their rabbis and building committees when a new synagogue is planned. No building is complete on the day it opens; there are continuing costs related to maintenance, unforeseen problems, new legal requirements, and demands of the congregation. Strict supervision of the budget is essential, with provision made for unforeseen problems. The building history at Lincoln Square suggests that hiring various levels of contractors be done on the basis of 
competence rather than price. The experience of this well-designed synagogue may prove exemplary for others contemplating a new sanctuary.

Young families often stay in the Lincoln Square area until the number of their children exceeds the capacity of available neighborhood apartments; they then move to suburban houses. The congregation has always required constant recruitment and internal renewal, as it does today. A congregation that has improved its facilities and has integrated them into the daily life of its members is the congregation that is likely to grow. Lincoln Square Synagogue's successful survival manifests the resilience of Orthodoxy despite secularization, intermarriage, and the competition of Conservative (European Reform) and Reform (European Liberal) synagogues. It also reflects the fidelity of the older long-time members, their sound supervision of the building, and the appeal and learning of Rabbi Robinson. For this congregation, the architects provided a sanctuary of which the members are proud and which adds joy to their Sabbath.

Funding: This research received no external funding.

Acknowledgments: I am grateful for the cooperation of CetraRuddy, Rabbi Shaul Robinson, and members of the building committee, especially Scott Liebman and Shelley Richman Cohen.

Conflicts of Interest: The author declares no conflicts of interest.

\section{References}

Abramson, Edward E. 2008. A Circle in the Square: Rabbi Sholom Riskin Reinvents the Synagogue. Jerusalem: Urim Publications; Brooklyn: Lambda Publications, Inc.

Dunlap, David. 2013. At Last, a New Lincoln Square Synagogue. New York Times, January 27.

Gardner, James. 2012. Lincoln Square's New Shul Looks Nothing Especially Synagogue-Like. The Real Deal. February 24. Available online: https://therealdeal.com/2012/02/14/lincoln-square-synagogue-looks-nothingespecially-synagogue-like/ (accessed on 30 March 2019).

Gruber, Samuel D. 2004. American Synagogues. Edited by Scott Tilden. New York: Rizzoli International.

Landowne, Morton. 2013. Entering Lincoln Square's Second Temple Period. The New York Jewish Week. January 15. Available online: jewishweek.timesofisrael.com/entering-lincoln-squares-second-temple-period/ (accessed on 10 April 2019).

Levin, Michael, and James E. Young. 2004. Jewish Identity in Contemporary Architecture. New York and Munich: Prestel.

Meek, Harold A. 1995. The Synagogue. London: Phaidon Press.

Millet, Marietta S. 1996. Light Revealing Architecture. New York: Van Nostrand Reinhold.

Rinaldi, Marco. 2013. Lincoln Square Synagogue by Cetra/Ruddy. Global Architecture Archive. March 2. Available online: https://aasarchitecture.com/2013/03/lioncoln-square-synagogue-by-cetraruddy.html (accessed on 30 March 2019).

Rosenblatt, Gary. 2013. If You Build It Will They Come? Jewish Week. January 2. Available online: https:/jewishweek.timesofisrael.com/if-you-build-it-will-they-come/ (accessed on 30 March 2019).

Stolzman, Henry, and Daniel Stolzman. 2004. Synagogue Architecture in America. Mulgrave: Images.

Torres, Elias. 2005. Zenithal Light. Barcelona: COAC.

(C) 2019 by the author. Licensee MDPI, Basel, Switzerland. This article is an open access article distributed under the terms and conditions of the Creative Commons Attribution (CC BY) license (http://creativecommons.org/licenses/by/4.0/). 